\title{
PENGARUH TERAPI MUSIK INSTRUMENTAL TERHADAP KUALITAS TIDUR PENDERITA INSOMNIA PADA LANSIA DI PANTI SOSIAL TRESNA WERDHA TERATAI PALEMBANG
}

\author{
Yudi Abdul Majid, M. Ali Sidik \\ Program Studi IImu Keperawatan \\ Sekolah Tinggi IImu Kesehatan Muhammadiyah Palembang \\ Email : yudi majid@yahoo.co.id
}

\begin{abstract}
ABSTRAK
Lansia merupakan seseorang yang telah mencapai usia 60 tahun keatas. Setiap tahun pertumbuhan lansia di dunia dan di Indonesia tumbuh semakin cepat. Meningkatnya jumlah lansia tersebut berhubungan dengan perubahan-perubahan yang dialaminya sesuai dengan bertambahnya umur, seperti penurunan kondisi fisik, fungsi-fungsi biologis, psikologis, dan sosial. Salah satu dampak dari perubahan fisik yang sering dialami lansia yaitu terjadinya gangguan tidur (insomnia) yang menyebabkan penurunan kualitas tidur pada penderitanya. Menurunya kualitas tidur pada lansia akan berdampak buruk terhadap kesehatan. Pengobatan yang dapat digunakan pada penderita insomnia yaitu dengan terapi farmakologi dan nonfarmakologi. Salah satu terapi nonfarmakologi yang dapat digunakan berupa terapi musik instrumental.Tujuan penelitian ini untuk mengetahui perbedaan rata-rata kualitas tidur antara sebelum dan sesudah intervensi terapi musik instrumental terhadap kualitas tidur penderita insomnia pada lansia di Panti Sosial Tresna Werdha Teratai Palembang 2017. Rancangan penelitian ini adalah pre-eksperimental dengan pendekatan one group pretest-posttest secara kuantitatif. Teknik sampling yang digunakan adalah total sampling dengan jumlah sampel 30 responden. Penelitian ini dilaksanakan pada tanggal 12 sampai dengan 19 April tahun 2017. Hasil analisis univariat diperoleh nilai rata-rata skor kualitas tidur lansia sebelum diberikan intervensi terapi musik instrumental yaitu 10,00 dan rata-rata skor kualitas tidur lansia sesudah diberikan intervensi terapi musik instrumental yaitu 5,00. Hasil analisis bivariat menggunakan uji Wilcoxon di peroleh nilai $p$ value 0,001 artinya terdapat perbedaan yang bermakna kualitas tidur responden sebelum dan sesudah diberikan intervensi terapi musik instrumental. Kesimpulan: Ada pengaruh terapi musik instrumental terhadap kualitas tidur penderita insomnia pada lansia di Panti Sosial Tresna Werdha Teratai Palembang 2017.
\end{abstract}

Kata Kunci : Musik Instrumental, Insomnia, Kualitas Tidur Lansia 


\section{PENDAHULUAN}

Undang-Undang Nomor 36 Tahun 2009 pasal 138 ayat 1 menetapkan bahwa upaya pemeliharaan kesehatan bagi lanjut usia harus ditujukan untuk menjaga agar tetap hidup sehat dan produktif secara sosial maupun ekonomis sesuai dengan martabat kemanusiaan. Menurut Undang-Undang Republik Indonesia Nomor 13 tahun 1998 tentang Kesejahteraan Lanjut Usia, yang dimaksud dengan lanjut usia (lansia) adalah seseorang yang telah mencapai usia 60 tahun keatas (Kemenkes RI, 2013).

Jumlah lansia di dunia tumbuh dengan sangat cepat bahkan tercepat dibandingkan kelompok usia lainnya. Saat ini jumlah lansia mencapai 500 juta dengan usia rata-rata 60 tahun. Menurut Unites National Populations Division pada tahun 2025 jumlah populasi lansia diperkirakan meningkat menjadi 1,2 milyar. Begitu juga jumlah penduduk lansia di Indonesia pada tahun 2005 mencapai 16,80 juta orang, angka ini naik menjadi 18,96 juta orang pada tahun 2007 dan menjadi 19,32 juta orang pada tahun 2009 (Komnas Lansia,2009). Berdasarkan hasil Susenas tahun 2014, jumlah lansia di Indonesia mencapai 20,24 juta orang atau sekitar $8,03 \%$ dari seluruh penduduk Indonesia dan diperkirakan pada tahun 2025, jumlahnya akan mancapai 36 juta jiwa (Kemenkes RI, 2016).

Data Dinas Kesehatan Provinsi Sumatera Selatan, pada tahun 2008 penduduk lansia Sumatera Selatan berjumlah 125.576 orang, tahun 2009 lansia berjumlah 155.222 orang. Pada tahun 2013 penduduk lansia Sumatera Selatan berjumlah 515,1 ribu orang, pada tahun 2014 berjumlah 522.240 orang. Pada tahun 2015penduduk lansia Sumatera Selatan tetap mengalami peningkatan hingga 561.712 orang atau ada sekitar $6,58 \%$ dari jumlah penduduk
Sumatera Selatan. Dari data diatas menunjukan kenaikan jumlah lansia setiap tahunnya di Provinsi Sumatera Selatan (BPS, 2015).

Meningkatnya jumlah lansia tersebut berhubungan dengan perubahan-perubahan yang dialaminya sesuai dengan bertambahnya umur, seperti penurunan kondisi fisik, fungsifungsi biologis, psikologis, dan sosial. Perubahan tersebut berdampak terhadap menurunya kemampuan jaringan secara perlahan-lahan untuk memperbaiki atau mengganti diri dan mempertahankan struktur serta fungsi normalnya. Akibatnya, tubuh tidak dapat bertahan terhadap kerusakan atau memperbaiki kerusakan tersebut. Salah satu dampak dari perubahan fisik yang sering dialami lansia adalah terjadinya insomnia (Muhith dan Sandu, 2016).

Insomnia merupakan ketidakmampuan memperoleh secara cukup kualitas dan kuantitas tidur (Tarwoto \& Wartonah, 2015). Insomnia dapat berupa kesulitan untuk tidur atau kesulitan untuk tetap tidur, bahkan seseorang yang terbangun dari tempat tidur tapi merasa belum cukup tidur dapat disebut mengalami insomnia (Wahyudi \& Wahid, 2016). $\mathrm{Hal}$ ini berhubungan dengan penurunan fungsifungsi pada sistem tubuh. Menurunya fungsi neurotransmiter menyebabkan menurunya produksi hormon melatonin yang berpengaruh terhadap perubahan irama sirkadian, Sehingga lansia akan mengalami penurunan yang progresif pada tahap tidur NREM 3 dan 4 , beberapa lansia hampir tidak memiliki tahap 4 , atau tidur yang dalam (Potter \& Perry, 2006). Seringkali faktor tunggal tidak hanya menjadi penyebab masalah tidur pada lansia, faktor fisiologi, psikologi, atau karena gangguan fisik, mental seperti perasaan gudah atau gelisah 
dapat mengubah kualitas dan kuantitas tidur (Wahyudi \& Wahid, 2016).

Menurunya kualitas tidur pada lansia akan berdampak buruk terhadap kesehatan. Secara fisiologis, jika seseorang tidak mendapatkan tidur yang cukup dapat menyebabkan penurunan nafsu makan, kelemahan, peningkatan angka kejadian kecelakaan baik di rumah maupun di jalan, terjatuh, iritabilitas, menyebabkan emosi menjadi tidak stabil, sulit untuk berkonsentrasi, dan kesulitan dalam mengambil suatu keputusan (Wold, 2004).

Berdasarkan dari permasalahan tersebut membutuhkan intervensi yang efektif untuk menangani penurunan kualitas tidur pada lansia yang mengalami insomnia. Cara yang dapat untuk membantu lansia yang mengalami insomnia dapat dengan menggunakan penatalaksanaan terapi farmakologi dan nonfarmakologi. Terapi farmakologi yang biasa digunakan dan dianggap paling efektif adalah obat tidur, akan tetapi jika digunakan terusmenerus seringkali akan memberi banyak masalah dari pada keuntungan (Potter \& Perry, 2006). Untuk itu perlu adanya upaya untuk mengatasi masalah insomnia yaitu dengan menggunakan terapi non farmakologi, terapi ini dapat membantu mengatasi masalah insomnia pada lansia. Terapi non farmakologi untuk penderita insomnia diantaranya terapi akupresur (Majid, 2014), mendengarkan murottal Al-Qur'an, terapi modalitas dan terapi musik (Djohan, 2006).

Terapi musik merupakan penggunaan musik atau elemen musik yang meliputi suara, irama, melodi, dan harmoni sebagai sebuah aktivitas terapeutik yang menggunakan musik sebagai media untuk memperbaiki, memelihara, mengembangkan mental, fisik, dan kesehatan emosi. Disamping kemampuan nonverbal, kreativitas dan rasa yang alamiah dari musik, juga sebagai fasilitator untuk menjalin hubungan, ekspresi diri, komunikasi, dan pertumbuhan pada penggunanya. Pada tahap selanjutnya, terapi musik difungsikan untuk memperbaiki kesehatan fisik, interaksi sosial, hubungan interpersonal, ekspresi emosi, dan meningkatkan kesehatan diri. Hal ini dikarenakan musik memiliki beberapa kelebihan, seperti bersifat universal, memberi ketenangan, rasa nyaman, menyenangkan, dan terstruktur (Djohan, 2006). Dalam Kamus Besar Bahasa Indonesia, musik merupakan ilmu atau seni menyusun nada atau suara dalam urutan, kombinasi, dan hubungan temporal untuk menghasilkan komposisi yang mempunyai kesatuan, kesinambungan, nada atau suara yang disusun demikian rupa sehingga mengandung irama, lagu, dan keharmonisan, terutama yang menggunakan alat-alat yang dapat menghasilkan bunyi-bunyi itu. Musik menjadi rangkaian nada-nada dan ritmik yang disusun secara teratur dan harmonis. Keteraturan tersebut membuat pendengar menikmati musik. Jika suara berasal dari alat musik maka musik disebut sebagai musik instrumental. Namun jika dilengkapi dengan vokal manusia maka dinamakan musik vokal.

Musik instrumental merupakan rangkaian nada-nada dari suara yang disusun sedemikian rupa dan dikombinasikan dari berbagai sumber suara yang diambil dari satu alat musik atau lebih tanpa ada vokal. Musik instrumental juga melibatkan hati, jiwa, dan pikiran baik bagi para pendengar atau pemain musik itu sendiri. Musik lembut dan teratur seperti instrumental merupakan musik yang dapat digunakan untuk terapi. Vibrasi atau getaran dari bunyi yang dihasilkan dari alat musik bermanfaat untuk 
mempengaruhi perubahan fisiologi, menurunkan tekanan darah, detak jantung, ketegangan otot, ACTH, sehingga akan menjadi lebih rileks (Djohan, 2006).

Secara fisiologis vibrasi dari bunyi musik yang dihasilkan masuk dari telinga, melalui serangkaian proses tersebut vibrasi diteruskan oleh sistem saraf menuju ke otak, kemudian otak akan menginterpretasikan menjadi suatu hal yang positif. Vibrasi dari bunyi yang dihasilkan dapat mempengaruhi peningkatkan hormon serotonin (Djohan, 2006). Serotonin akan berperan sebagai neurotransmiter yang membawa sinyal ke otak untuk menstimulus kelenjar pineal untuk memproduksi hormon melatonin. Kemudian hormon melatonin ini akan mempengaruhi suprachiasmatic nucleus (SCN) di hipotalamus anterior otak dalam pengaturan ritme sirkadian sehingga terjadi penurunan sleep latency, nocturnal awakening, dan peningkatan total sleep time dan kualitas tidur.

Studi pendahuluan yang dilakukan oleh peneliti di Panti Sosial Tresna Werdha Teratai Palembang pada tanggal 11 januari 2017. Didapat jumlah lansia yang tinggal di Panti Sosial Tresna Werdha Teratai Palembang sebanyak 70 orang. Peneliti melakukan wawancara kepada lansia yang berjumlah 20 orang, di dapatkan yang mengalami insomnia sebanyak 16 orang. Lansia mengatakan kesulitan dalam memulai tidur, tidak dapat mempertahankan tidur karena sering terbangun di malam hari, dan bangun lebih awal tetapi kesulitan untuk tidur kembali. Lansia rata-rata tidur hanya 2-5 jam. Jika di bandingkan dengan kebutuhan tidur lansia minimal 6 jam sehari, jelas bahwa mengalami penurunan kualitas tidur.
Dari pembahasan diatas, maka peneliti tertarik melaksanakan penelitian mengenai pengaruh terapi musik instrumental terhadap kualitas tidur penderita insomnia pada lansia di Panti Sosial Tresna Werdha Teratai Palembang 2017.

\section{METODE PENELITIAN}

Desain dalam penelitian ini adalah preeksperimental dengan pendekatan one group pretest-postest, dalam desain ini tidak ada kelompok control. Teknik sampling yang digunakan dalam penelitian ini adalah dengan menggunakan total sampling yaitu semua anggota populasi dijadikan sebagai sampel penelitian, karena menurut Sugiyono (2007) jumlah populasi yang kurang dari 100 seluruh populasi dijadikan sampel penelitian semuanya. Sampel yang diambil dari penelitian ini adalah 30 orang.

Alat yang digunakan untuk mengumpulkan data yaitu lembar kuesioner Pittsburg Sleep Quality Index (PSQI). Uji statistik yang digunakan adalah uji alternatif Wilcoxon.

\section{HASIL PENELITIAN}

Karakteristik Responden

1. Umur

Tabel 1. Distribusi Frekuensi Responden Berdasarkan Umur

\begin{tabular}{cccc}
\hline No & Umur & Jumlah & Persentase (\%) \\
\hline 1 & $60-74$ & 16 & 53,3 \\
2 & $75-90$ & 14 & 46,7 \\
\hline \multicolumn{2}{c}{ Jumlah } & 30 & 100 \\
\hline
\end{tabular}


Dari tabel tersebut diketahui umur responden terbanyak pada rentang umur 60-74 dengan jumlah 16 orang (53,3\%).

2. Jenis Kelamin

Tabel 2. Distribusi Frekuensi Responden Berdasarkan Jenis Kelamin

\begin{tabular}{cccc}
\hline No & $\begin{array}{c}\text { Jenis } \\
\text { Kelamin }\end{array}$ & Jumlah & $\begin{array}{c}\text { Persentase } \\
(\%)\end{array}$ \\
\hline 1 & Laki-laki & 12 & 40 \\
2 & Perempuan & 18 & 60 \\
\hline & Jumlah & 30 & 100 \\
\hline
\end{tabular}

Dapat diketahui bahwa dari 30 responden, jenis kelamin terbanyak yaitu perempuan dengan jumlah 18 orang (60,0 \%).

3. Pendidikan

Tabel 3. Distribusi Frekuensi Responden Berdasarkan Pendidikan

\begin{tabular}{clcc}
\hline No & Pendidikan & Jumlah & $\begin{array}{c}\text { Presentase } \\
(\mathbf{\%})\end{array}$ \\
\hline 1 & $\begin{array}{l}\text { Tidak } \\
\text { sekolah }\end{array}$ & 11 & 36,7 \\
2 & SD & 10 & 33,3 \\
3 & SMP & 6 & 20 \\
4 & SMA & 3 & 10 \\
\hline & Jumlah & 30 & 100 \\
\hline & Dapat & diketahui & bahwa dari 30
\end{tabular}

responden, tingkat pendidikan terbanyak yaitu tidak sekolah berjumlah 11 orang (36,7\%).

4. Status pernikahan

Tabel 4. Distribusi Frekuensi Responden Berdasarkan Status Pernikahan

\begin{tabular}{|c|c|c|c|}
\hline no & $\begin{array}{c}\text { Status } \\
\text { Pernikahan }\end{array}$ & Jumlah & Presentase (\%) \\
\hline 1 & Menikah & 11 & 36,7 \\
\hline 2 & $\begin{array}{l}\text { Tidak } \\
\text { menikah }\end{array}$ & 2 & 6,7 \\
\hline 3 & Duda/janda & 17 & 56,7 \\
\hline \multicolumn{2}{|r|}{ Jumlah } & 30 & 100 \\
\hline
\end{tabular}

Dapat diketahui bahwa dari 30 responden, status pernikahan terbanyak yaitu duda/janda dengan jumlah 17 responden (56,7 $\%)$.

5. Suku

Tabel 5. Distribusi Frekuensi Responden Berdasarkan Suku Bangsa

\begin{tabular}{clcc}
\hline No & $\begin{array}{c}\text { Suku } \\
\text { Bangsa }\end{array}$ & Jumlah & $\begin{array}{c}\text { Presentase } \\
\mathbf{( \% )}\end{array}$ \\
\hline 1 & Palembang & 20 & 66,7 \\
2 & Jawa & 6 & 20 \\
3 & Sunda & 2 & 6,7 \\
4 & Padang & 1 & 3,3 \\
5 & Batak & 1 & 3,3 \\
\hline & Jumlah & 30 & 100 \\
\hline
\end{tabular}

Dapat diketahui bahwa dari 30 responden, suku bangsa terbanyak yaitu suku palembang dengan jumlah 20 responden $(66,7 \%)$.

6. Lama tinggal di panti

Tabel 6. Distribusi Frekuensi Responden Berdasarkan Lama Tinggal di Panti

\begin{tabular}{|c|c|c|c|}
\hline No & $\begin{array}{c}\text { Lama } \\
\text { Tinggal di } \\
\text { Panti }\end{array}$ & Jumlah & $\begin{array}{c}\text { Presentase } \\
(\%)\end{array}$ \\
\hline 1 & $<1$ tahun & 12 & 40 \\
\hline 2 & $1-10$ tahun & 15 & 50 \\
\hline 3 & $\begin{array}{l}11-20 \\
\text { tahun }\end{array}$ & 3 & 10 \\
\hline & Jumlah & 30 & 100 \\
\hline
\end{tabular}

responden, distribusi lansia tinggal di panti lebih banyak selama 1-10 tahun dengan jumlah 15 responden (50,0\%).

7. Skor Komponen Kualitas Tidur

Tabel 7. Skor Komponen Kualitas Tidur Lansia Sebelum dan Sesudah Intervensi Terapi Musik Instrumental 


\begin{tabular}{|c|c|c|c|c|c|}
\hline $\begin{array}{l}\mathrm{N} \\
\mathrm{O}\end{array}$ & $\begin{array}{c}\text { Komponen } \\
\text { Kualitas } \\
\text { Tidur }\end{array}$ & Mean & Median & $\begin{array}{l}\text { Min- } \\
\text { Max }\end{array}$ & $\begin{array}{c}\text { Stan } \\
\text { dar } \\
\text { Devi } \\
\text { asi }\end{array}$ \\
\hline 1 & $\begin{array}{l}\text { Kualitas Tidur } \\
\text { Subjektif } \\
\text { Pretest } \\
\text { Postest }\end{array}$ & $\begin{array}{l}1,83 \\
1,00\end{array}$ & $\begin{array}{l}2 \\
1\end{array}$ & $\begin{array}{l}1-3 \\
0-2\end{array}$ & $\begin{array}{l}0,834 \\
0,371\end{array}$ \\
\hline 2 & $\begin{array}{l}\text { Masa Laten } \\
\text { Tidur } \\
\text { Pretest } \\
\text { Postest }\end{array}$ & $\begin{array}{l}2,27 \\
1,20\end{array}$ & $\begin{array}{l}2 \\
1\end{array}$ & $\begin{array}{l}1-3 \\
0-2\end{array}$ & $\begin{array}{l}0,640 \\
0,484\end{array}$ \\
\hline 3 & $\begin{array}{l}\text { Durasi Tidur } \\
\text { Pretest } \\
\text { Postest }\end{array}$ & $\begin{array}{l}2,93 \\
1,20\end{array}$ & $\begin{array}{l}3 \\
1\end{array}$ & $\begin{array}{l}2-3 \\
1-2\end{array}$ & $\begin{array}{l}0,254 \\
0,407\end{array}$ \\
\hline 4 & $\begin{array}{l}\text { Efisiensi Tidur } \\
\text { Pretest } \\
\text { Postest }\end{array}$ & $\begin{array}{l}1,77 \\
0,40\end{array}$ & $\begin{array}{l}1 \\
0\end{array}$ & $\begin{array}{l}1-3 \\
0-2\end{array}$ & $\begin{array}{l}0,898 \\
0,675\end{array}$ \\
\hline 5 & $\begin{array}{l}\text { Gangguan } \\
\text { Tidur dimalam } \\
\text { Hari } \\
\text { Pretest } \\
\text { Postest }\end{array}$ & $\begin{array}{l}1,10 \\
1,00\end{array}$ & $\begin{array}{l}1 \\
1\end{array}$ & $\begin{array}{c}1-2 \\
1\end{array}$ & $\begin{array}{l}0,305 \\
0,000\end{array}$ \\
\hline 6 & $\begin{array}{l}\text { Gangguan } \\
\text { Tidur disiang } \\
\text { Hari } \\
\text { Pretest } \\
\text { Postest }\end{array}$ & $\begin{array}{l}1,20 \\
1,00 \\
\end{array}$ & $\begin{array}{l}1 \\
1 \\
\end{array}$ & $\begin{array}{l}1-2 \\
0-1 \\
\end{array}$ & $\begin{array}{l}0,407 \\
0,305 \\
\end{array}$ \\
\hline
\end{tabular}

Dapat diketahui bahwa peningkatan skor kualitas tidur terbanyak terdapat pada komponen durasi tidur dengan nilai median sebelum intervensi terapi musik yaitu sebesar 3 dan nilai min-max (2-3) dan nilai median sesudah intervensi yaitu sebesar 1 dan minmax (1-2), yang memiliki nilai penurunan median sebesar 2 .

\section{Skor Kualitas Tidur Sebelum Intervensi}

Tabel 8. Skor Kualitas Tidur Lansia Sebelum Intervensi Terapi Musik Instrumental

\begin{tabular}{lccccc}
\hline $\begin{array}{c}\text { Kualitas } \\
\text { Tidur }\end{array}$ & Mean & Median & $\begin{array}{c}\text { Min- } \\
\text { Max }\end{array}$ & SD & Cl \\
\hline & & & & & 10,22 \\
Pretest & 11,10 & 10,00 & $8-16$ & 2,354 & $\begin{array}{c}- \\
11,98\end{array}$ \\
\hline
\end{tabular}

Dapat diketahui bahwa nilai median kualitas tidur sebelum diberikan terapi musik instrumental yaitu 10,00 dengan standar deviasi 2,354, skor terendah 8 dan skor tertinggi yaitu 16. Hasil confidence interval mengindikasikan bahwa 95\% diyakini skor rata-rata kualitas tidur lansia berkisar antara 10,22 - 11,98.

\section{Skor Kualitas Tidur Sesudah}

Tabel 9. Skor Kualitas Tidur Lansia Sesudah Terapi Musik Instrumental

\begin{tabular}{lccccc}
\hline $\begin{array}{c}\text { Kualitas } \\
\text { Tidur }\end{array}$ & Mean & Median & $\begin{array}{c}\text { Min- } \\
\text { Max }\end{array}$ & SD & Cl \\
\hline Posttest & 5,70 & 5,00 & $4-10$ & 1,622 & $\begin{array}{c}5,09- \\
6,31\end{array}$ \\
\hline \multicolumn{4}{c}{ Dapat diketahui } & bahwa & terdapat
\end{tabular}

penurunan nilai median kualitas tidur sesudah diberikan intervensi terapi musik instrumental yaitu 5,00 dengan standar deviasi 1,622, skor terendah 4 dan skor tertinggi yaitu 10. Hasil confidence interval mengindikasikan bahwa 95\% diyakini skor rata-rata kualitas tidur lansia berkisar antara 5,09-6,31.

10.Skor kualitas tidur sebelum dan sesudah intervensi

Tabel 10. Perbedaan Skor PSQI antara Sebelum dan Sesudah Intervensi

\begin{tabular}{lccccc}
\hline $\begin{array}{c}\text { Kualitas } \\
\text { Tidur }\end{array}$ & Mean & Median & $\begin{array}{c}\text { Min- } \\
\text { Max }\end{array}$ & SD & $p$ \\
\hline Pretest & 11,10 & 10,00 & $8-16$ & 2,354 & \\
Posttest & 5,70 & 5,00 & $4-10$ & 1,622 & \\
\hline
\end{tabular}

Dapat diketahui bahwa nilai median kualitas tidur global sebelum diberikan intervensi terapi musik instrumental yaitu 10,00 dan nilai kualitas tidur sesudah diberikan intervensi yaitu 5,00. Hasil analisis uji wilcoxon skor kualitas tidur global sesudah intervensi di peroleh nilai $p=0,001 \quad(p<0,05)$, maka Ha ditolak artinya ada perbedaan kualitas tidur antara sebelum dan sesudah diberikan terapi musik instrumental pada lansia. 


\section{PEMBAHASAN}

1. Kualitas tidur sebelum intervensi

Berdasarkan hasil analisis univariat sebelum diberikan intervensi terapi musik instrumental dari 30 responden diketahui nilai median yaitu 10,00 dengan standar deviasi 2,354, skor terendah 8 dan skor tertinggi yaitu 16. Hasil confidence interval mengindikasikan bahwa 95\% diyakini skor rata-rata kualitas tidur lansia berkisar antara 10,22 - 11,98. Skor kualitas tidur diperoleh dari pengisian kuesioner PSQI, dikatakan kualitas tidur baik jika skor $\leq 5$ dan kualitas tidur buruk jika skor $>5$. Dengan demikian, dapat disimpulkan bahwa sebagian besar responden memiliki kualitas tidur yang buruk sebelum diberikan intervensi terapi musik instrumental.

Hal ini didukung oleh hasil penelitian diketahui bahwa dari 30 responden, jumlah umur terbanyak yaitu dalam rentang umur 60-74 dengan jumlah 16 orang (53,3 \%). Menurut Wahyudi \& Wahid tahun 2016 bertambahnya umur pada lansia akan mengalami penurunan kondisi fisik, fungsi-fungsi biologis, psikologis, dan sosial. Perubahan tersebut berdampak terhadap menurunya kemampuan jaringan secara perlahan-lahan untuk memperbaiki atau mengganti diri dan mempertahankan struktur serta fungsi normalnya. Akibatnya, tubuh tidak dapat bertahan terhadap kerusakan atau memperbaiki kerusakan tersebut (Wahyudi \& Wahid, 2016).

Menurut Potter \& Perry tahun 2006 penurunan fungsi pada sistem tubuh akan berdampak pada penurunan fungsi neurotransmiter sehingga menyebabkan penurunan produksi hormon melatonin yang berpengaruh terhadap perubahan irama sirkadian, sehingga lansia akan mengalami penurunan yang progresif pada tahap tidur
NREM 3 dan 4, beberapa lansia hampir tidak memiliki tahap 4, atau tidur yang dalam (Potter \& Perry, 2006). Menurut Siregar tahun 2011 menyatakan penurunan kualitas tidur mencakup aspek kuantitatif seperti durasi tidur, latensi tidur, serta aspek subjektif seperti tidur dalam dan istirahat.

Hal ini sesuai dengan penelitian Merlianti tahun 2014 di Panti Jompo Graha Kasih Bapa Kabupaten Kubu Raya diperoleh skor rata-rata yaitu 23,94, nilai ini menunjukan ke dalam kategori insomnia berat. Insomnia merupakan kesulitan tidur yang muncul berulang kali. Gejalanya seperti tidak bisa tidur, sering terbangun pada malam hari karena mimpi buruk, gelisah saat tidur, atau mengantuk disiang hari karena jam tidur yang kurang (Merlianti, 2014).

Dari hasil penelitian yang didapatkan dan teori yang mendukung serta beberapa penelitian terkait dengan demikian peneliti berpendapat bahwa faktor penyebab penurunan kualitas tidur pada lansia disebabkan oleh beberapa faktor seperti lingkungan yang bising, cuaca yang panas dan fasilitas yang kurang mendukung, sedangkan faktor internal disebabkan oleh penurunan kondisi fisik, fungsi biologis, dan psikologis. Terjadinya penurunan fungsi sistem tubuh berdampak pada penurunan fungsi neurotransmiter sehingga menyebabkan penurunan produksi hormon melatonin yang berpengaruh terhadap perubahan irama sirkadian, sehingga lansia akan mengalami penurunan yang progresif pada tahap tidur NREM 3 dan 4, beberapa lansia hampir tidak memiliki tahap 4, atau tidur yang dalam dan menyebabkan penurunan komponen kualitas tidur yang meliputi, kualitas tidur yang subjektif, masa laten tidur, durasi tidur, efisiensi tidur, 
gangguan tidur dimalam hari, dan gangguan tidur disiang.

2. Kualitas tidur sesudah intervensi

Berdasarkan hasil analisis univariat sesudah diberikan intervensi terapi musik instrumental dari 30 responden terlihat penurunan skor nilai median yaitu 5,00 dengan standar deviasi 1,622, skor terendah 4 dan skor tertinggi yaitu 10. Hasil confidence interval mengindikasikan bahwa 95\% diyakini skor ratarata kualitas tidur lansia berkisar antara 5,09 6,31. Skor kualitas tidur diperoleh dari pengisian kuesioner PSQI, dikatakan kualitas tidur baik jika skor $\leq 5$ dan kualitas tidur buruk jika skor $>5$. Dengan demikian, dapat disimpulkan bahwa terdapat penurunan yang signifikan sesudah dilakukan intervensi terapi musik instrumental.

Menurut ahli dari pusat gangguan tidur di Amerika menyatakan bahwa terapi musik yang diberikan selama 30-60 menit setiap hari menjelang waktu tidur, secara teratur selama satu minggu cukup efektif untuk meningkatkan kualitas tidur (Djohan, 2016).. Teori ini diterapkan dalam penelitian ini dengan memberikan terapi musik instrumental selama 30 menit selama 4 hari pada hari sabtu, minggu, senin dan selasa. Musik instrumental yang diberikan dalam tempo lambat sesuai dengan kesukaan lansia.

Menurut Djohan tahun 2016 menyatakan bahwa terapi musik merupakan penggunaan musik atau elemen musik yang meliputi suara, irama, melodi, dan harmoni sebagai sebuah aktivitas terapeutik yang menggunakan musik sebagai media untuk memperbaiki, memelihara, mengembangkan mental, fisik, dan kesehatan emosi. Berdasarkan manfaatnya vibrasi dari bunyi yang dihasilkan dari alat musik dapat mempengaruhi perubahan fisiologi, menurunkan tekanan darah, detak jantung, ketegangan otot, ACTH, sehingga seseorang yang mendengarkanya akan menjadi lebih rileks, nyaman dan tenang (Djohan, 2016).

Hal ini ada kesamaan dengan hasil penelitian yang dilakukan oleh Rembulan tahun 2014, sesudah diberikan terapi musik intrumental terdapat penurunan skor nilai ratarata yaitu 6,14. Menurut Djohan tahun 2016, dikarenakan musik sebagai sebuah aktivitas terapiutik yang menggunakan musik sebagai media untuk memperbaiki, memelihara, membangun mental, fisik, dan kesehatan emosi. Musik juga memiliki beberapa kelebihan, seperti bersifat universal, memberi ketenangan, kenyamanan, dan menyenangkan (Djohan, 2006, Rembulan, 2014).

Dari hasil penelitian yang didapatkan dan teori yang mendukung serta beberapa penelitian terkait menunjukan bahwa terjadi penurunan skor kualitas tidur pada lansia sesudah diberikan terapi musik instrumental, hal ini di dukung oleh pernyataan lansia bahwa sesudah mendengarkan musik instrumental tidur dimalam hari semakin nyenyak dan perasaan lebih nyaman, tenang, dan lebih rileks, hal ini dikarenakan musik instrumental merupakan sebuah aktivitas terapiutik yang menggunakan musik sebagai media untuk memperbaiki, memelihara, membangun mental, fisik, dan kesehatan emosi. Selain itu musik instrumental juga bersifat universal, yang bermanfaat untuk mempengaruhi perubahan fisiologi, menurunkan tekanan darah, detak jantung, ketegangan otot, ACTH, sehingga seseorang yang mendengarkanya akan menjadi lebih rileks, nyaman dan menenangkan.

3. Kualitas tidur sebelum dan setelah intervensi

Berdasarkan hasil analisis bivariat sebelum dilakukan intervensi terapi musik 
instrumental diperoleh nilai median yaitu 10,00 dengan standar deviasi 2,354, dan sesudah diberikan intervensi diperoleh nilai median yaitu 5,00 dengan standar deviasi 1,622. Hasil analisis uji wilcoxon skor kualitas tidur global sesudah intervensi di peroleh nilai $p=0,001$ $(p<0,05)$, maka $\mathrm{Ha}$ ditolak artinya ada perbedaan kualitas tidur antara sebelum dan sesudah diberikan terapi musik instrumental pada lansia

Menurut Djohan tahun 2016, terapi musik merupakan penggunaan musik atau elemen musik yang meliputi suara, irama, melodi, dan harmoni sebagai sebuah aktivitas terapeutik yang menggunakan musik sebagai media untuk memperbaiki, memelihara, mengembangkan mental, fisik, dan kesehatan emosi. Disamping kemampuan nonverbal, kreativitas dan rasa yang alamiah dari musik, juga sebagai fasilitator untuk menjalin hubungan, ekspresi diri, komunikasi, dan pertumbuhan pada penggunanya. Pada tahap selanjutnya, terapi musik difungsikan untuk memperbaiki kesehatan fisik, interaksi sosial, hubungan interpersonal, ekspresi emosi, dan meningkatkan kesadaran diri. Hal ini dikarenakan musik memiliki beberapa kelebihan, seperti bersifat universal, memberi ketenangan, rasa nyaman, menyenangkan, dan terstruktur (Djohan, 2016).

Hal ini didukung dengan Djohan tanun 2016, bahwa musik yang berirama lembut dan teratur mempengaruhi keadaan fisik dan mental seseorang. Vibrasi dan harmonisasi musik dapat mempengaruhi perubahan fisiologi, menurunkan tekanan darah, detak jantung, ketegangan otot, ACTH (hormone stress) sehingga yang mendengarkanya menjadi rileks. Berdasarkan mekanisme kerjanya secara fisiologis vibrasi dari bunyi musik yang dihasilkan masuk dari telinga, melalui serangkaian proses tersebut vibrasi diteruskan oleh sistem saraf menuju ke otak, kemudian otak akan menginterpretasikan menjadi suatu hal yang positif. Kemudian vibrasi menstimulus peningkatkan hormon serotonin. Kemudian menurut pernyataan Iswari \& Wahyuni (2013) serotonin akan berperan sebagai neurotransmiter yang membawa sinyal ke otak untuk menstimulus kelenjar pineal untuk memproduksi hormon melatonin, kemudian hormon melatonin ini akan mempengaruhi suprachiasmatic nucleus ( $\mathrm{SCN}$ ) di hipotalamus anterior otak dalam pengaturan ritme sirkadian sehingga terjadi penurunan sleep latency, nocturnal awakening, peningkatan total sleep time dan kualitas tidur (Djohan, 2016).

Hal ini ada kesamaan dengan hasil penelitian yang dilakukan oleh Astriawan (2016), dengan $p$-value sebesar 0,041 ( $\alpha=0,05)$, artinya ada pengaruh musik instrumental terhadap kualitas tidur pasien rawat inap yang mengalami gangguan tidur di RSUD Ungaran.

Berdasarkan hasil analisis statistik terhadap setiap komponen kualitas tidur sebelum dan sesudah dilakukan intervensi terapi musik instrumental pada lansia yang meliputi, kualitas tidur yang subjektif, masa laten tidur, durasi tidur, efisiensi tidur, gangguan tidur dimalam hari, dan gangguan tidur disiang hari, terdapat perbedaan yang signifikan pada komponen 3 yaitu durasi tidur, pada pretest diperoleh nilai median 3 , nilai min-max 2-3 sedangkan posttest nilai median 1 dengan nilai min-max 1-2, sehingga terlihat perbedaan penurunan nilai median sebesar 2 , dengan demikian terdapat hubungan yang kuat antara terapi musik instrumental terhadap penurunan atau perbaikan skor pada komponen durasi tidur. 
Menurut Djohan tahun 2016, respon reaksi yang didapatkan dari terapi musik instrumental membuat lansia merasa lebih tenang, lebih rileks dan nyaman. Vibrasi dari musik instrumental dapat mempengaruhi peningkatkan hormon serotonin. kemudian serotonin akan berperan sebagai neurotransmiter yang membawa sinyal ke otak untuk menstimulus kelenjar pineal untuk memproduksi hormon melatonin. Kemudian hormon melatonin ini akan mempengaruhi suprachiasmatic nucleus (SCN) di hipotalamus anterior otak dalam pengaturan ritme sirkadian sehingga lansia akan mengalami peningkatan pada tahap tidur NREM 3 dan 4, atau tidur yang dalam (Djohan, 2016).

Dari hasil penelitian yang didapatkan dan teori yang mendukung serta beberapa penelitian terkait menunjukan bahwa terdapat perbedaan skor kualitas tidur antara sebelum dan sesudah diberikan intervvensi terapi musik instrumental pada lansia di Panti Sosial Tresna Werdha Teratai Palembang. Dengan demikian, peneliti berpendapat bahwa terapi musik instrumental yang meliputi suara, irama, melodi, dan harmoni dari alat musik merupakan sebuah aktivitas terapeutik yang menggunakan musik sebagai media untuk memperbaiki, memelihara, mengembangkan mental, fisik, dan kesehatan emosi. Secara fisiologis terapi musik dapat mempengaruhi perubahan fisiologi, menurunkan tekanan darah, detak jantung, ketegangan otot, ACTH, sehingga seseorang yang mendengarkanya akan menjadi lebih rileks. Terapi musik juga dapat menstimulus pengeluaran hormon melatonin yang akan mempengaruhi suprachiasmatic nucleus ( $\mathrm{SCN}$ ) di hipotalamus anterior otak dalam pengaturan ritme sirkadian sehingga terjadi peningkatan total sleep time dan kualitas tidur yang mencakup aspek kuantitatif seperti durasi tidur, latensi tidur, efisiensi tidur dan tidur yang lebih dalam. Berdasarkan hasil penelitian dengan teori yang ada, maka peneliti berpendapat bahwa terapi musik instrumental dapat meningkatkan kualitas tidur pada lansia.

\section{SIMPULAN}

\section{Tujuan Umum}

Ada pengaruh terapi musik instrumental terhadap kualitas tidur penderita insomnia pada Iansia di Panti Sosial Tresna Werdha Teratai Palembang 2017.

\section{Tujuan Khusus}

Hasil penelitian diperoleh 30 responden di Panti Sosial Tresna Werdha Teratai Palembang 2017. Dilakukan pada tanggal 12 sampai dengan 19 April, maka dapat disimpulkan sebagai berikut:

a. Rata-rata skor kualitas tidur lansia sebelum diberikan intervensi terapi musik instrumental yaitu 10,00.

b. Rata-rata skor kualitas tidur lansia sesudah diberikan intervensi terapi musik instrumental yaitu 5,00 .

c. Hasil analisis uji Wilcoxon terhadap kualitas tidur sebelum dan sesudah intervensi menunjukkan nilai $p$ value= $0,001(<0,05)$, artinya ada perbedaan kualitas tidur antara sebelum dan sesudah diberikan terapi musik instrumental, dengan persentase mencapai $67 \%$.

\section{SARAN}

1. Panti Sosial Tresna Werdha Teratai Palembang

Disarankan bagi petugas panti dalam meningkatkan kualitas tidur pada lansia 
dengan memerhatikan kondisi lingkungan, kenyamanan, kebersihan tempat tidur, kemudian mempertimbangkan jumlah lansia dalam satu ruangan untuk menghindari kebisingan dan hasil dari penelitian ini dapat digunakan sebagai acuan informasi dan masukan untuk mengatasi gangguan tidur khususnya pada lansia dengan pemberian terapi musik instrumental.

2. Bagi Institusi Pendidikan

Diharapkan hasil penelitian ini dapat dijadikan sebagai bahan referensi untuk meningkatkan pengetahuan dan dapat diterapkan dalam pembelajaran untuk penanganan gangguan tidur tentang pengaruh terapi musik instrumental terhadap peningkatan kualitas tidur lansia.

3. Bagi Peneliti Selanjutnya

Disarankan bagi peneliti lain dapat mengembangkan penelitian lanjutan mengenai terapi nonfarmakologi musik instrumental, yang meliputi :

a. Pengaruh terapi musik instrumental terhadap kualitas tidur penderita insomnia pada lansia dengan rancangan penelitian quasi experimen dengan pendekatan pre and post test control group.

b. Perbandingan terapi musik instrumental dengan terapi nonfarmakologi lain seperti terapi akupresur dan musik klasik.

c. Peneliti lanjutan dengan membandingkan keefektifitas pemberian terapi musik instrumental antara siang dan malam hari.

d. Peneliti lanjutan dapat memasukan faktor confounding seperti kebiasaan meminum kopi dn merokok kedalam kriteria ekslusi agar faktor ini tidak mempengaruhi hasil penelitian.

\section{DAFTAR PUSTAKA}

Badan Pusat Statistik. (2015). Statistik Penduduk Lanjut Usia Tahun 2015. Sumatera Selatan: Badan Pusat Statistik.

Djohan. (2006). Terapi Musik. Yogyakarta: Galangpress

Kementerian Kesehatan RI. (2016). Pusat Data dan Informasi. Jakarta selatan.

Komisi Nasional Lanjut Usia. (2009). Profil Penduduk Lanjut Usia. Jakarta: Komnas Nasional Lanjut Usia.

Kementerian Kesehatan RI. (2013). Pusat Data dan Informasi. Jakarta selatan.

Merlianti, A. (2014). Pengaruh Terapi Musik Terhadap Kualitas Tidur Penderita Insomnia Pada Lanjut Usia (Lansia) di Panti Jompo Graha Kasih Bapa Kabupaten Kubu Raya. Pontianak: Universitas Tanjungpura.

Majid, Y.A. (2014). Pengaruh Akupresur Terhadap Kualitas Tidur Lansia Balai Perlindungan Sosial Tresna Werdha Ciparay. Universitas Padjadjaran

Muhith, A \& Sandu, S. (2016). Pendidikan Keperawatan Gerontik. Yogyakarta: Andi.

Potter \& Perry. (2006). Buku Ajar Fundamental Keperawatan. Edisi4. Jakarta: EGC

Rembulan, M.P. (2014). Pengaruh Musik Instrumental dan Aromatherapy Lavender Eyemask Terhadap Penurunan Tingkat Insomnia Pada Mahasiswa 
Fisioterapi D3 Angkatan 2011. Surakarta:

Fakultas IImu Kesehatan Universitas

Muhammadiyah.

Tarwoto \& Wartonah. (2015). Kebutuhan Dasar Manusia dan Proses Keperawatan. Jakarta: Selemba Medika.

Wahyudi \& Wahid. (2016). Buku Ajar IImu Keperawatan Dasar. Jakarta: Mitra Wacana Media

Wold, G.H. (2004). Basic Geriatri Nursing. Amerika: 3th ed. Mosby. 